\title{
Residual Effect of Different Sources of Nutrients on Available Micronutrients in Soil After Harvest of Maize in Rice Fallow Maize Cropping System
}

\author{
MOHANA RAO PULI ${ }^{1}$, P.R.K. PRASAD ${ }^{2}$, P. RAVINDRA BABU ${ }^{3}$, K.L. NARASIMHA RAO ${ }^{4}$, G. SUBBAIAH AND M. $^{5}$ \\ JAYA LAKSHMI ${ }^{6}$
}

${ }^{1,2,3}$ SSAC ${ }^{4}$ Plant Physiology and ${ }^{5} \mathrm{Ag}$. College, Bapatla. Department of Soil Science and Agricultural Chemistry, Agricultural College, Bapatla

\begin{abstract}
A field experiment was conducted for two consecutive years (2011-2012 and 2012-2013) on fine texture soils of Agricultural college farm, Bapatla. The experiment was laid out in a randomized block design in kharif season with four treatments. The treatments consisted of $M_{1}$ (RDF - Control), $M_{2}$ (10t FYM ha ${ }^{-1}+$ RDF), $M_{3}$ (1.5t vermicompost ha $^{-1}+$ RDF), $M_{4}$ (Green manuring + RDF). During the immediate rabi, the experiment was laid out in a split-plot design without disturbing the soil for succeeding maize with the four treatments given to kharif rice as main plot treatments and each of these divided into five sub-plots to receive five levels of fertilizer NPK application viz., $\mathrm{N}_{1}$ $75 \%$ NPK, $N_{2}-100 \%$ NPK, $N_{3}-125 \%$ NPK, $N_{4}-150 \%$ NPK and $\mathrm{N}_{5}-175 \%$ NPK for succeeding maize. Data collected on available micronutrients after harvest of maize crop were significantly increased with the application of $100 \%$ NPK in combination with FYM@10t ha ${ }^{-1}$ to preceding rice crop, irrespective of the NPK levels applied to succeeding maize crop. However, it was on par with that of green manuring together with $100 \%$ NPK during both the years of the study.
\end{abstract}

Keywords FYM, green manuring, vermicompost, available NPK

\section{MATERIALS AND METHODS}

Experiment was conducted in the field number 49A and $49 \mathrm{~B}$ of the Agricultural College Farm, Bapatla, during the years 2011-12 and 2012-13, respectively. Prior to preparatory cultivation of the experimental site, soil samples from 0 to $15 \mathrm{~cm}$ depth were collected at random and a composite soil sample during both the years was analyzed for different physico-chemical properties. The results of the soil analytical data indicated that the experimental soil is clay and sandy clay during first and second year, respectively in texture, slightly alkaline in reaction, low in organic carbon $(0.52$ and $0.50 \%$ during first and second year, respectively) and available nitrogen (175.6 and $159.8 \mathrm{~kg}$ $\mathrm{ha}^{-1}$ during first and second year, respectively), and high in available phosphorus (95.3 and $93.9 \mathrm{~kg} \mathrm{P}_{2} \mathrm{O}_{5} \mathrm{ha}^{-1}$ during first and second year, respectively) and potassium (960.0 and $925.6 \mathrm{~kg} \mathrm{~K}_{2} \mathrm{O} \mathrm{ha} \mathrm{h}^{-1}$ during first and second year, respectively). The experiment consisted of four treatments viz., $\mathrm{M}_{1}$ (RDF - Control), $\mathrm{M}_{2}$ (10t FYM ha-1 + RDF), $\mathrm{M}_{3}(1.5 \mathrm{t}$ vermicompost ha-1 $+R D F), M_{4}$ (Green manuring $\left.+R D F\right)$.

The experiment is laid out in RBD and replicated five times. The recommended fertilizer dose was applied as 160:40:40 kg N, $\mathrm{P}_{2} \mathrm{O}_{5}$ and $\mathrm{K}_{2} \mathrm{O} \mathrm{ha}^{-1}$. During the immediate rabi, the experiment was laid out in a split-plot design without disturbing the soil for succeeding maize with the four treatments given to kharif rice as main plot treatments and each of these divided into five sub-plots to receive five levels of fertilizer NPK application viz., $\mathrm{N}_{1}-75 \% \mathrm{NPK}$, $\mathrm{N}_{2}-100 \%$ NPK, $\mathrm{N}_{3}-125 \%$ NPK, $\mathrm{N}_{4}-150 \%$ NPK and $\mathrm{N}_{5}-$ $175 \%$ NPK for succeeding maize. The experiment on rice maize sequence as detailed above was repeated on a separate site but in the same block during kharif 2012 and rabi 2013, respectively. Popular cultivars of rice and maize,

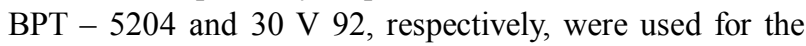
study.

FYM and vermicompost were added 7 days before transplanting of rice on dry weight basis. Dhaincha crop was raised with the seed rate of $60 \mathrm{~kg} \mathrm{ha}^{-1}$ in individual plots and it was incorporated 7 days before transplanting of rice as green manure at flowering stage. Nitrogen was applied in the form of DAP and remaining $\mathrm{N}$ was applied in the form of urea, in three equal splits, first split at 10 DAS, second split at knee high stage and third split at tasseling stage. Half dose of $\mathrm{K}$ and full dose of $\mathrm{P}$ was applied, in the form of $\mathrm{MoP}$ and DAP respectively, at 10 days after sowing. Remaining half dose of $\mathrm{K}$ was applied at tasseling stage. All fertilizers were applied in pocketing method as per the treatments.

Plot wise surface (0-15) soil sample were collected immediately after harvest of rice. The soil samples were air dried in shade, ground and screened through $2 \mathrm{~mm}$ sieve and used for laboratory analysis. Soil reaction $(\mathrm{pH})$ was measured by using glass electrode $\mathrm{pH}$ meter in 1:2.5 ratio of soil water suspension (Jackson, 1973), Conductivity is measured with supernant liquid of 1:2.5 soil water suspensions by using electrical conductivity meter (Jackson, 1973). Available nitrogen was estimated by alkaline permanganate method by using macro Kjeldahl distillation unit (Subbiah and Asija, 1956). Available phosphorus was extracted with Olsen's reagent (Olsen et al., 1954), and estimated using spectrophotometer as described by Watanabe and Olsen (1965). Available potassium was extracted with neutral normal ammonium acetate and estimated with the help of flame photometer (Jackson, 1973). Micronutrients (Fe, Mn, Cu, Zn) were extracted with DTPA and estimated with the help of AAS (Lindsay and Norvell, 1978).

\section{RESULTS AND DISCUSSION}

\section{Available Fe}

Irrespective of rate of NPK level applied to maize in the sequence, the status of available Fe after harvest of maize was significantly higher following organic application 
together with $100 \%$ NPK than that of inorganic alone given to preceding rice crop during first year of study whereas, all the treatments were on par during second year of study. These results were in accordance with the findings of Singh et al. (1999) who reported that the application of balanced fertilizer with FYM (NPK + FYM and NPK + FYM + Zn) showed significantly higher DTPA - Fe content than other treatments after 10 years of rice-wheat cropping sequence.

Irrespective of nutrient management given to preceding rice, the status of available Fe in soil after harvest of succeeding maize increased with increasing level of NPK from 75 to $100 \%$ to succeeding maize whereas, the available Fe status was decreased from $100 \%$ NPK to $175 \%$ NPK. It might be due to antagonistic and imbalance effect in between nutrients. However, application of organics to preceding rice crop could able to reduce antagonism effect (Table 1). Increase in available Fe with the increasing dose of fertilizer might be due to lowering of $\mathrm{pH}$ and thereby to increasing the solubility of metallic elements (Prasad et al., 2010). Sudhakar et al. (2002) also reported that application of chemical fertilizers along with vermicompost resulted in greater availability of micronutrients.

The mean highest available Fe was recorded in the treatment $M_{2}$ and $M_{3}$ with $24.4 \mathrm{ppm}$ followed by $M_{4}$ with $24.1 \mathrm{ppm}$ during first year of the study whereas, it was recorded in the treatment $\mathrm{M}_{2}$ with $28.0 \mathrm{ppm}$ followed by $\mathrm{M}_{4}$ with $27.2 \mathrm{ppm}$ during second year of the study. The enhancement in the available Fe due to the addition of organic substances might be ascribed to their ability to form stable water soluble complexes preventing the reaction with other soil constituents and also increasing the $\mathrm{Fe}$ content by releasing it from the native reserves (Gupta et $a l .$, 1988). The interaction effect was found statistically significant. The highest available Fe was recorded in the treatment $\mathrm{M}_{2} \mathrm{~N}_{2}$ with 26.5 and 30.1ppm in 2012 and 2013, respectively.

\section{Available Mn}

The data presented in table 2 indicated that irrespective of rate of NPK level applied to maize in the sequence, the status of available Mn after harvest of maize was significantly higher following FYM application @ 10t ha $^{-1}$ together with $100 \%$ NPK $\left(\mathrm{M}_{2}\right)$ than that of inorganic alone $\left(\mathrm{M}_{1}\right)$ provided to preceding rice crop during both the years of study. Whereas, the maize grown on plots those received vermicompost @ 1.5t ha ${ }^{-1}$ in combination with $100 \%$ NPK $\left(\mathrm{M}_{3}\right)$ and green manure $+100 \%$ NPK (M4) in preceding kharif season, were on par with inorganic alone $\left(\mathrm{M}_{1}\right)$ followed to preceding rice crop. The available $\mathrm{Mn}$ status increased with the addition of FYM. This might be due to the release of $\mathrm{Mn}^{2+}$ bound to organic ligands in the organic matter and acceleration of the reduction of $\mathrm{Mn}^{4+}$ to $\mathrm{Mn}^{2+}$ (Selvi and Augustine, 1997).

Irrespective of nutrient management followed to preceding rice, the status of available $\mathrm{Mn}$ in soil after harvest of succeeding maize almost maintained the same level with increasing level of NPK from 75 to $100 \%$ to succeeding maize whereas, the available Mn status was decreased from $100 \%$ NPK to $175 \%$ NPK. The higher reduction of available $\mathrm{Mn}$ was recorded with the application of $175 \%$ NPK to succeeding maize following $100 \%$ NPK alone to preceding rice $(2.20$ and $2.47 \mathrm{ppm}$ during first and second year of the study). It might be due to antagonistic effect and imbalance among nutrients. However, application of organics to preceding rice crop could able to reduce antagonism effect nutrient status became balance. The mean highest available $\mathrm{Mn}$ was recorded in the treatment $\mathrm{M}_{2}$ with 3.00 and $3.12 \mathrm{ppm}$ followed by $\mathrm{M}_{3}$ with 2.76 and $\mathrm{M}_{4}$ with $3.00 \mathrm{ppm}$ during first and second year of the study, respectively. The interaction effect was found statistically significant. The highest available $\mathrm{Mn}$ was recorded in the treatment $\mathrm{M}_{2} \mathrm{~N}_{1}$ with $3.59 \mathrm{ppm}$ followed by $\mathrm{M}_{3} \mathrm{~N}_{1}$ with $3.39 \mathrm{ppm}$ during first year of the study whereas, the highest was in the treatment $\mathrm{M}_{2} \mathrm{~N}_{2}$ with $3.63 \mathrm{ppm}$ followed by $\mathrm{M}_{2} \mathrm{~N}_{1}$ with $3.59 \mathrm{ppm}$ during second year of the study.

\section{Available Cu}

Irrespective of rate of NPK level applied to maize in the sequence, the status of available $\mathrm{Cu}$ after harvest of maize was higher following organic application together with $100 \%$ NPK than that of inorganic alone given to preceding rice crop during both the years of study except $\mathrm{M}_{3}$ in 2012. The status of available $\mathrm{Cu}$ in soil after harvest of succeeding maize decreased with increasing level of NPK from 75 to $175 \%$ or 100 to $175 \%$ to succeeding maize (Table 3). The highest available $\mathrm{Cu}$ was recorded in the treatment $\mathrm{M}_{4} \mathrm{~N}_{1}$ with $4.07 \mathrm{ppm}$ followed by $\mathrm{M}_{2} \mathrm{~N}_{1}$ with $4.03 \mathrm{ppm}$ during first year of the study whereas, the highest was recorded in the treatment $\mathrm{M}_{2} \mathrm{~N}_{1}$ with $3.98 \mathrm{ppm}$ followed by $\mathrm{M}_{2} \mathrm{~N}_{2}$ with $3.97 \mathrm{ppm}$ during second year of the study. These results were in conformity with the findings of Sinha et al. (1997) who noticed higher available $\mathrm{Cu}$ content in $\mathrm{N}$ alone treatment compared to $\mathrm{N}$ applied in combination with $\mathrm{P}$ and $\mathrm{K}$ indicating that the $\mathrm{P}$ and $\mathrm{K}$ had adverse effects on available copper content.

\section{Available Zn}

Irrespective of rate of NPK level applied to maize in the sequence, the status of available $\mathrm{Zn}$ after harvest of maize was significantly higher following organics application together with $100 \%$ NPK than that of inorganic alone given to preceding rice crop during both the years of study, except the maize grown on plots those received vermicompost@1.5 ha ${ }^{-1}$ in combination with 100\% NPK and green manure in combination with $100 \%$ NPK in preceding kharif season, which were on par with inorganic alone given to preceding rice crop during first year of study. The mean highest available $\mathrm{Zn}$ was recorded in the treatment $\mathrm{M}_{2}$ with 3.52 and 3.42ppm in 2012 and 2013, respectively followed by $\mathrm{M}_{3}$ with $3.23 \mathrm{ppm}$ in 2012 and $\mathrm{M}_{4}$ with $3.35 \mathrm{ppm}$ in 2013. The interaction effect was found statistically significant. The highest available $\mathrm{Zn}$ was recorded in the treatment $\mathrm{M}_{2} \mathrm{~N}_{1}$ with 4.07 and $4.00 \mathrm{ppm}$ in 2012 and 2013, respectively.

Irrespective of nutrient management followed to preceding rice, the status of available $\mathrm{Zn}$ in soil after harvest of succeeding maize decreased with increasing level of NPK from 75 to $175 \%$ to succeeding maize. This decrease was statistically significant during second year of the study and during first year this decrease was significant with increased 50\% NPK level (Table 4). Level above 125\% NPK 
Table 1. Influence of organics applied to preceding rice crop and NPK levels on available Fe (ppm) in soil after harvest of maize.

\begin{tabular}{|c|c|c|c|c|c|c|c|c|c|c|}
\hline \multirow{3}{*}{ NPK levels } & \multicolumn{4}{|c|}{ 2011-2012 } & \multirow{3}{*}{ Mean } & \multicolumn{4}{|c|}{ 2012-2013 } & \multirow{3}{*}{ Mean } \\
\hline & \multicolumn{4}{|c|}{ Organics applied to preceding rice crop } & & & $\begin{array}{l}\text { rganics ap } \\
\text { eceding ri }\end{array}$ & $\begin{array}{l}\text { plied } \\
\text { ice cro }\end{array}$ & & \\
\hline & M1 & M2 & M3 & M4 & & M1 & M2 & M3 & M4 & \\
\hline $\mathrm{N} 1-75 \% \mathrm{RDF}$ & 24.4 & 25.9 & 25.4 & 25.3 & 25.2 & 28.4 & 29.2 & 28.7 & 28.7 & 28.7 \\
\hline $\mathrm{N} 2-100 \% \mathrm{RDF}$ & 24.5 & 26.5 & 26.0 & 25.6 & 25.6 & 29.2 & 30.1 & 28.3 & 28.2 & 28.9 \\
\hline N3-125\% RDF & 21.6 & 25.0 & 24.6 & 25.9 & 24.3 & 27.6 & 28.3 & 27.2 & 27.2 & 27.6 \\
\hline N4-150\% RDF & 19.4 & 24.0 & 23.8 & 22.0 & 22.3 & 24.7 & 26.6 & 25.8 & 26.0 & 25.8 \\
\hline N5-175\% RDF & 16.5 & 20.5 & 22.5 & 21.7 & 20.3 & 23.8 & 25.8 & 25.2 & 25.7 & 25.1 \\
\hline \multirow[t]{2}{*}{ Mean } & 21.3 & 24.4 & 24.4 & 24.1 & 23.5 & 26.7 & 28.0 & 27.0 & 27.2 & 27.2 \\
\hline & $\mathrm{SEm} \pm$ & $\begin{array}{c}C D \\
(p=0.05)\end{array}$ & CV (\%) & & & $\begin{array}{l}\text { SEm } \\
\pm\end{array}$ & $\begin{array}{c}C D \\
(p=0.05)\end{array}$ & $\begin{array}{l}\text { CV } \\
(\%)\end{array}$ & & \\
\hline M & 0.60 & 2.1 & 9.9 & & & 0.42 & 1.5 & 6.0 & & \\
\hline $\mathrm{N}$ & 0.60 & 1.7 & 8.9 & & & 0.47 & 1.4 & 6.0 & & \\
\hline \multicolumn{11}{|l|}{$\mathrm{M} \times \mathrm{N}$ Interaction } \\
\hline $\mathrm{N}$ at same $\mathrm{M}$ & 1.20 & 3.5 & & & & 0.95 & 2.7 & & & \\
\hline $\begin{array}{l}\mathrm{M} \text { at same or diff. } \mathrm{N} \\
\text { level }\end{array}$ & 1.23 & 2.5 & & & & 0.94 & 1.9 & & & \\
\hline
\end{tabular}

$M_{1}-$ RDF (Control), $M_{2}-$ FYM 10t ha-1 + RDF, $M_{3}$ - Vermicompost $1.5 t$ ha $^{-1}+R D F, M_{4}$ - Green manuring + RDF

$\mathrm{M}$ - Organics applied to preceding rice crop

$\mathrm{N}$ - Nutrient levels applied to maize crop

Table 2. Influence of organics applied to preceding rice crop and NPK levels on available Mn in soil after harvest of maize.

\begin{tabular}{|c|c|c|c|c|c|c|c|c|c|c|}
\hline \multirow{3}{*}{ NPK levels } & \multicolumn{4}{|c|}{ 2011-2012 } & \multirow{3}{*}{ Mean } & \multirow{2}{*}{\multicolumn{4}{|c|}{$\begin{array}{l}\frac{2012-2013}{} \\
\text { Organics applied to } \\
\text { preceding rice crop }\end{array}$}} & \multirow{3}{*}{ Mean } \\
\hline & \multicolumn{4}{|c|}{ Organics applied to preceding rice crop } & & & & & & \\
\hline & M1 & M2 & M3 & M4 & & M1 & M2 & M3 & M4 & \\
\hline N1-75\% RDF & 3.20 & 3.59 & 3.39 & 3.29 & 3.37 & 3.13 & 3.59 & 3.32 & 3.36 & 3.35 \\
\hline N2-100\% RDF & 2.92 & 3.30 & 3.04 & 3.10 & 3.09 & 3.16 & 3.63 & 3.37 & 3.37 & 3.38 \\
\hline N3-125\% RDF & 2.45 & 2.75 & 2.74 & 2.43 & 2.59 & 2.98 & 2.95 & 2.94 & 2.93 & 2.95 \\
\hline N4-150\% RDF & 2.37 & 2.68 & 2.38 & 2.40 & 2.46 & 2.61 & 2.78 & 2.58 & 2.68 & 2.66 \\
\hline N5-175\% RDF & 2.20 & 2.66 & 2.27 & 2.26 & 2.35 & 2.47 & 2.65 & 2.53 & 2.64 & 2.57 \\
\hline \multirow[t]{2}{*}{ Mean } & 2.63 & 3.00 & 2.76 & 2.70 & 2.77 & 2.87 & 3.12 & 2.95 & 3.00 & 2.98 \\
\hline & $\mathrm{SEm} \pm$ & $\begin{array}{c}C D \\
(p=0.05)\end{array}$ & CV $(\%)$ & & & $\begin{array}{l}\text { SEm } \\
\pm\end{array}$ & $\begin{array}{c}C D \\
(p=0.05)\end{array}$ & $\begin{array}{l}\text { CV } \\
(\%)\end{array}$ & & \\
\hline M & 0.098 & 0.34 & 13.7 & & & 0.064 & 0.22 & 8.3 & & \\
\hline $\mathrm{N}$ & 0.089 & 0.26 & 11.1 & & & 0.079 & 0.23 & 9.2 & & \\
\hline \multicolumn{11}{|l|}{ M x N Interaction } \\
\hline $\mathrm{N}$ at same $\mathrm{M}$ & 0.178 & 0.51 & & & & 0.158 & 0.45 & & & \\
\hline $\begin{array}{l}\mathrm{M} \text { at same or diff. } \mathrm{N} \\
\text { level }\end{array}$ & 0.187 & 0.39 & & & & 0.155 & 0.32 & & & \\
\hline
\end{tabular}

$\mathrm{M}_{1}$ - RDF (Control), $\mathrm{M}_{2}-\mathrm{FYM} 10 \mathrm{tha} \mathrm{h}^{-1}+\mathrm{RDF}, \mathrm{M}_{3}$ - Vermicompost $1.5 \mathrm{t} \mathrm{ha} \mathrm{h}^{-1}+\mathrm{RDF}, \mathrm{M}_{4}$ - Green manuring $+\mathrm{RDF}$

$\mathrm{M}$ - Organics applied to preceding rice crop

$\mathrm{N}$ - Nutrient levels applied to maize crop 
Table 3. Influence of organics applied to preceding rice crop and NPK levels on available $\mathrm{Cu}(\mathrm{ppm})$ in soil after harvest of maize.

\begin{tabular}{|c|c|c|c|c|c|c|c|c|c|c|}
\hline \multirow{3}{*}{ NPK levels } & \multicolumn{4}{|c|}{ 2011-2012 } & \multirow{3}{*}{ Mean } & \multirow{2}{*}{\multicolumn{4}{|c|}{$\begin{array}{l}\frac{2012-2013}{} \\
\text { Organics applied to } \\
\text { preceding rice crop }\end{array}$}} & \multirow{3}{*}{ Mean } \\
\hline & \multicolumn{4}{|c|}{ Organics applied to preceding rice crop } & & & & & & \\
\hline & M1 & M2 & M3 & M4 & & M1 & M2 & M3 & M4 & \\
\hline N1-75\% RDF & 3.87 & 4.03 & 3.93 & 4.07 & 3.98 & 3.77 & 3.98 & 3.81 & 3.80 & 3.84 \\
\hline N2-100\% RDF & 3.66 & 3.90 & 3.18 & 3.44 & 3.54 & 3.79 & 3.97 & 3.91 & 3.84 & 3.88 \\
\hline N3-125\% RDF & 3.40 & 3.40 & 3.14 & 3.12 & 3.27 & 3.13 & 3.34 & 3.25 & 3.59 & 3.33 \\
\hline N4-150\% RDF & 2.70 & 2.80 & 2.77 & 2.90 & 2.79 & 2.73 & 2.93 & 2.67 & 3.10 & 2.86 \\
\hline N5-175\% RDF & 2.46 & 2.53 & 2.33 & 2.50 & 2.45 & 2.59 & 2.71 & 2.46 & 2.83 & 2.65 \\
\hline \multirow[t]{2}{*}{ Mean } & 3.22 & 3.33 & 3.07 & 3.21 & 3.21 & 3.21 & 3.39 & 3.22 & 3.43 & 3.31 \\
\hline & $\mathrm{SEm} \pm$ & $\begin{array}{c}C D \\
(p=0.05)\end{array}$ & CV (\%) & & & $\mathrm{SEm} \pm$ & $\begin{array}{l}\text { CD } \\
p=0.05)\end{array}$ & $\begin{array}{l}\text { CV } \\
(\%)\end{array}$ & & \\
\hline M & 0.107 & 0.37 & 12.9 & & & 0.047 & 0.16 & 5.5 & & \\
\hline $\mathrm{N}$ & 0.098 & 0.28 & 10.6 & & & 0.080 & 0.23 & 8.4 & & \\
\hline \multicolumn{11}{|l|}{$\mathrm{M} \times \mathrm{N}$ Interaction } \\
\hline $\mathrm{N}$ at same $\mathrm{M}$ & 0.196 & 0.56 & & & & 0.160 & 0.46 & & & \\
\hline $\begin{array}{l}\mathrm{M} \text { at same or diff. } \mathrm{N} \\
\text { level }\end{array}$ & 0.205 & 0.43 & & & & 0.151 & 0.31 & & & \\
\hline
\end{tabular}

$M_{1}-$ RDF (Control), $M_{2}-F Y M 10 t h^{-1}+R D F, M_{3}-$ Vermicompost $1.5 \mathrm{t} \mathrm{ha}^{-1}+R D F, M_{4}-$ Green manuring + RDF

$\mathrm{M}$ - Organics applied to preceding rice crop

$\mathrm{N}$ - Nutrient levels applied to maize crop

Table 4. Influence of organics applied to preceding rice crop and NPK levels on available Zn (ppm) in soil after harvest of maize.

\begin{tabular}{|c|c|c|c|c|c|c|c|c|c|c|}
\hline \multirow{3}{*}{ NPK levels } & \multicolumn{4}{|c|}{ 2011-2012 } & \multirow{3}{*}{ Mean } & \multicolumn{4}{|c|}{$2012-2013$} & \multirow{3}{*}{ Mean } \\
\hline & \multicolumn{4}{|c|}{ Organics applied to preceding rice crop } & & \multicolumn{4}{|c|}{$\begin{array}{l}\text { Organics applied to } \\
\text { preceding rice crop }\end{array}$} & \\
\hline & M1 & M2 & M3 & M4 & & M1 & M2 & M3 & M4 & \\
\hline N1-75\% RDF & 3.63 & 4.07 & 3.86 & 3.77 & 3.83 & 3.70 & 4.00 & 3.84 & 3.94 & 3.87 \\
\hline $\mathrm{N} 2-100 \% \mathrm{RDF}$ & 3.36 & 3.95 & 3.53 & 3.40 & 3.56 & 3.06 & 3.86 & 3.59 & 3.65 & 3.54 \\
\hline N3-125\% RDF & 2.99 & 3.36 & 3.06 & 2.95 & 3.09 & 2.92 & 3.36 & 3.25 & 3.27 & 3.20 \\
\hline $\mathrm{N} 4-150 \% \mathrm{RDF}$ & 2.75 & 3.18 & 2.94 & 2.81 & 2.92 & 2.45 & 3.19 & 2.84 & 3.03 & 2.88 \\
\hline N5-175\% RDF & 2.47 & 3.02 & 2.74 & 2.67 & 2.73 & 2.19 & 2.70 & 2.42 & 2.86 & 2.54 \\
\hline \multirow[t]{2}{*}{ Mean } & 3.04 & 3.52 & 3.23 & 3.12 & 3.23 & 2.86 & 3.42 & 3.19 & 3.35 & 3.21 \\
\hline & $\mathrm{SEm} \pm$ & $\begin{array}{c}C D \\
(p=0.05)\end{array}$ & $\mathrm{CV}(\%)$ & & & $\begin{array}{c}\text { SEm } \\
\pm\end{array}$ & $\begin{array}{c}C D \\
(p=0.05)\end{array}$ & $\begin{array}{l}\text { CV } \\
(\%)\end{array}$ & & \\
\hline M & 0.067 & 0.23 & 8.0 & & & 0.049 & 0.17 & 5.9 & & \\
\hline $\mathrm{N}$ & 0.106 & 0.31 & 11.4 & & & 0.078 & 0.22 & 8.4 & & \\
\hline \multicolumn{11}{|l|}{$\mathrm{M} \times \mathrm{N}$ Interaction } \\
\hline $\mathrm{N}$ at same $\mathrm{M}$ & 0.212 & 0.61 & & & & 0.155 & 0.45 & & & \\
\hline $\begin{array}{l}\text { M at same or diff. } \mathrm{N} \\
\text { level }\end{array}$ & 0.201 & 0.41 & & & & 0.147 & 0.3 & & & \\
\hline
\end{tabular}

$\mathrm{M}_{1}-\mathrm{RDF}$ (Control), $\mathrm{M}_{2}-\mathrm{FYM} 10 \mathrm{t} \mathrm{ha} \mathrm{t}^{-1}+\mathrm{RDF}, \mathrm{M}_{3}$ - Vermicompost $1.5 \mathrm{t} \mathrm{ha}^{-1}+\mathrm{RDF}, \mathrm{M}_{4}$ - Green manuring $+\mathrm{RDF}$

$\mathrm{M}$ - Organics applied to preceding rice crop

$\mathrm{N}$ - Nutrient levels applied to maize crop 
may be detrimental either due to formation of complexes at higher $\mathrm{P}$ levels with other nutrients i.e. antagonistic effect with Zn (Kacar and Katkat, 1998; Rupa et al., 2003), or limitation of $\mathrm{N}$ and K nutrients in soil (Karimian, 1995). Hence, $125 \%$ NPK might be the optimum level under the field condition.

The DTPA extractable micronutrients [zinc ( $\mathrm{Zn})$, iron $(\mathrm{Fe})$, manganese $(\mathrm{Mn})$, and copper $(\mathrm{Cu})]$ decreased greatly with $150 \mathrm{~kg} \mathrm{~N}^{-1}$ over control (Singh et al., 2000a). This was perhaps due to higher removal of micronutrients by the rice crop. Green manuring either maintained or increased the concentration of micronutrients in the soil (Singh et al., 1992). While availability of $\mathrm{Zn}$ in soil under FYM treatment was higher than or on par with that of other organic-amended plots, available Fe content was low in FYM amended soil (Singh et al., 2000b). The depletion rate of DTPA- extractable micronutrients was higher in soils treated with chemical fertilizers alone as compared to the plots that received both fertilizers and organic manures after completion of 12 cycles of rice-wheat sequence in an Inceptisol (Yadav and Kumar, 1998).

\section{LITERATURE CITED}

Gupta, A.P., Antil, R.S., Norvell, R.P. 1988. Effect of FYM on organic carbon, available N, P content of soil during different periods of wheat growth. Journal of Indian Society of Soil Science, 36: 269-273.

Jackson, M.L. 1973. Soil chemical analysis. Prentice Hall of India Private Ltd., New Delhi : 134-182.

Kacar, B and Katkat, A.V. 1998. Bitki Besleme. Ludag Universites Guclendirme Vakfi Yayini. No.127.

Karimian, N. 1995. Effect of nitrogen and phosphorus on zinc nutrient of corn in Nutrition, 18(10): 2261-2271.

Olsen, S.R., Code, C.L., Watanable, F.S and Dean, L.A. 1954. Estimation of available phosphorus in soils by extraction with sodium bicarbonate. United States Development Agency Circular Number 939.

Prasad, J., Karmakar, S., Kumar, R and Mishra, B. 2010. Influence of integrated nnutrient management on yield and soil properties in maize-wheat cropping system in an Alfisol of Jharkhand. Journal of the Indian Society of Soil Science, 58(2): 200-204.

Rupa, T.R., Rao, C.S., Rao, A.S and Singh, M. 2003. Effect of farm yard manure and phosphorus on zinc transformations and phytoavailability in two Alfisols of India. Bioresource Technology, 87(3): 279-288.

Selvi, R and Augustine, S.D. 1997. Effect of mushroom spent rice straw compost on soil physical properties of alluvial and laterite soils. Madras Agricultural Journal, 84(1):15-19.

Singh, A.K., Amgain, L.P and Sharma, S.K. 2000a. Root characteristics, soil physical properties and yield of rice (Oryza sativa) as influenced by integrated nutrient management in ricewheat system. Indian Journal of Agronomy, 45(2): 217-222.

Singh, B., Singh, Y., Sadana, U.S and Meelu, O.P. 1992. Effect of green manure, wheat straw and organic manures on DTPA extractable $\mathrm{Fe}, \mathrm{Mn}, \mathrm{Zn}$ and $\mathrm{Cu}$ in a calcareous sandy loam soil at field capacity and under water logged conditions. Journal of the Indian Society of Soil Science, 40: 114-118.

Singh, N.P., Sachan, R.S., Pandey, P.C and Bisht, P.S.1999. Effect of decade long fertilizer and manure application on soil fertility and productivity of rice- wheat system in a Mollisol. Journal of the Indian society of Soil Science, 47(1): 72-80.

Singh, Y., Singh, B., Meelu, O.P and Khind, C.S. 2000b. Long-term effects of organic manuring and crop residues on the productivity and sustainability of rice-wheat cropping system in northwest India. Page 149-162 in long-term soil fertility experiments in rice-wheat cropping systems (Abrol, I.P., Bronson, K. F., Duxbury, J. M. and Gupta, R. K. eds.). Rice - Wheat Consortium Paper Series 6. New Delhi, India: Rice-Wheat Consortium for the IndoGangetic Plains.

Sinha, S.K., Singh, V.N and Singh, P. 1997. Effect of continuous use of fertilisers on physical and physico-chemical properties of an alluvial soil. Journal of Research (BAU), 9(1): 31-34.

Subbiah, B.V and Asija, C.L. 1956. A rapid procedure for the estimation of available nitrogen in soils. Current Science. 25: $259-260$.

Sudhakar, G., Christopher, L., Raj, A., Rangasamy, A., Subbian, P and Velayutham, A. 2002. Effect of vermicompost application on the soil properties, nutrient availability, uptake and yield of rice - a review. Agricultural Review, 23(2): 127-133.

Watanabe, F.S. and Olsen, S.R. 1965. Test of ascorbic acid method fordetermining phosphorous in water and sodium bicarbonate extracts of soil.Soil Science Society of American Journal. 29:677-78

Yadav, D.S and Kumar, A. 1998. Integrated use of organics and inorganics in rice-wheat cropping system for sustainable production IPNS system for sustainable productivity. IIPSS (pub): 247(Eds. Swarup, Reddy and Prasad).

Received on 04-10-2017

Accepted on 18-11-2017 